Article

\title{
Exploring the Enablers of Strategic Orientation for Technology-Driven Business Innovation Ecosystems
}

\author{
Ta-Kai Yang ${ }^{1}$ and Min-Ren Yan ${ }^{2, *}$ \\ 1 Department of International Business Administration, Chinese Culture University, Taipei City 106, Taiwan; \\ tkyang@sce.pccu.edu.tw \\ 2 College of Business, Chinese Culture University, Taipei City 106, Taiwan \\ * Correspondence: ymr3@faculty.pccu.edu.tw
}

Received: 8 September 2019; Accepted: 12 October 2019; Published: 18 October 2019

check for updates

\begin{abstract}
The present study explores the impacts of corporate strategic orientation on innovation ecosystems through the perspective of systems thinking. Multiple-cases method was adopted to analyze three representative companies of different industries. In terms of academic contribution, the results of this study verify an innovation ecosystem model in a generalized manner, and find that market orientation, interaction orientation, and entrepreneurial orientation generate a positively reinforcing effect on the paths of the innovation ecosystem model in all phases, thus, diversifying the available literature of innovative ecosystems. In terms of practical contribution, this study presents a dynamic context of the development of new business, and describes the links between innovative activities and the market. Enterprises can refer to the proposed framework as well as strategic architecture in this study to effectively transform innovative activities into market performance.
\end{abstract}

Keywords: innovation ecosystem; market orientation; interaction orientation; entrepreneurial orientation; business model; systems thinking; sustainable system development

\section{Introduction}

In recent years, many enterprises regard technology as the way to drive business operations and implement business strategies, as the technology-driven business model stimulates enterprises' continuous innovation and growth [1]. This trend highlights the fact that strategic orientation plays a key role in the sustainable growth of organizations $[2,3]$.

The impact of strategic orientation on the competitive advantage of enterprises has been extensively discussed in previous studies $[4,5]$. For example, when a company has excellent market orientation (MO), it has excellent market performance [6,7], as it understands customers' wants and potential needs better than its competitors do, and consequently, show better competitiveness and strategies. The interaction orientation (IO) of a company is important to new product development (NPD), as it is able to effectively interact with individual customers [8,9]. When a company has entrepreneurial orientation (EO), its product innovation activities will be driven and higher corporate performance will be generated [10-12]. However, these arguments are mainly based on competition among enterprises, while ignoring the co-evolution amid the cooperation and conflict between enterprises and other members of the overall environment [13]. Moreover, regarding the competitive advantage of companies, a systematic point of view that discusses these strategic orientations remains absent till nowadays, and the perspective on integration of strategic orientation is still unclear.

Enterprises are in a complex and competitive business environment. According to the open systems perspective, it is difficult for enterprises to develop all resources and technologies independently, thus, they must rely on external resources [14-17] to overcome resource constraints $[18,19]$, which makes co-evolution a necessary business model. As different ecological groups depend on each other 
in an ecosystem, the members of the economic community feature co-existence and co-evolution to ensure the development of the business ecosystem [20]. For example, by providing software, hardware, and services, Xiaomi has fostered a disruptive innovation model that should not be underestimated by the global technology industry; the iPhone-centered ecosystem, as created by Apple, delivers a complete customer experience, which shows that competition is no longer confined to enterprises, but to ecosystems [21,22]. Successful innovation relies on cooperation among members of the ecosystem in which the enterprise is located [23], meaning that under such paradigm shift, it is an important academic and practical topic to understand the impact of strategic orientation on the ecosystem of enterprises and to create competitive advantage [24,25].

In retrospect, to examine how the research streams of an innovation ecosystem evolves in different periods, the present study finds that this concept was raised around 2000. Initially, the literature mainly explored the elements of the innovation ecosystem, and focused on the roles played by these elements in the ecosystem, such as outsourcing R\&D, technology in-sourcing [14,26], and open innovation platforms $[27,28]$. As there is more research on this concept, the focus shifts to the industry application of the innovation ecosystem, such as the type [29] or the composition [30] of the innovation ecosystems. The concept of innovation ecosystem has increasingly gained ground in the literature on strategy, innovation, and entrepreneurship [31-34]. Recent research has just begun to explore the interaction between the external environment and ecosystem, such as science parks [35], and the impact of governmental organizations on the ecosystem [31,36]. These studies have laid a solid theoretical foundation for the research of innovation ecosystems. However, most previous studies tended to observe individual cases at the industrial level, while research at the corporate level is scarce. In addition, most of these studies focused on a single case or conceptual description without comparing different industries; therefore, the applicability of innovation ecosystem models must be clarified. Moreover, EO, MO, and IO seem to be complementary for the corporate competitive advantage. The observation of similar arguments shows that more and more studies use different strategic-orientation combinations to observe company performance $[37,38]$. However, the impact of different strategy-oriented combinations on the development path of innovation ecosystems awaits clarification. Finally, technological innovation and the development of new business are complex [39]. Different ways of development are affected by the logic of different strategic orientations, and at present, few studies have explored the complete dynamic context. Therefore, in order to fill the existing theoretical gap, this paper presents a case study of three companies in different industries in Taiwan, and intends to discuss the role of strategic orientation in the innovation ecosystem from a corporate-level perspective. In addition, this study observes the impact of strategic orientation on technological innovation and new market development.

This study contributes to the innovation ecosystem theory by intending to answer the following questions. Firstly, from the perspective of corporate-level strategic orientation, this study constructs a dynamic development process of the links among technological innovation, market development, and business model. In addition to strengthening the theoretical basis of the innovation ecosystem model, micro-analysis can help enterprises understand how to interpret, decide, and act to create a successful blueprint of business models. Secondly, this study develops the causal loop models of three different industries; through the comparison and induction of multiple cases, the innovation ecosystem theory can be verified in a generalized manner. Finally, aiming at two factors in the innovation ecosystem model, this study observes technological innovation and new market development to determine the driving force and development trajectories of technological innovation and new market development, in order that enterprises can understand the development process of innovative and market systems.

This study includes the following parts. Firstly, the background of an innovation ecosystem is described on the basis of literature review, the research framework is developed, and the essence and implication of strategic orientation is introduced. Secondly, the research methods and case analysis are 
presented. Finally, the research results are discussed, and the theoretical and managerial implications are highlighted in such discussion.

\section{Literature Review}

\subsection{Theoretical Background: Systems Thinking and Innovation Ecosystem}

The concept of an innovation ecosystem model can be derived from the logic of systems thinking, which is intended to evaluate the interactive relationships between two or more components and the environment from a holistic viewpoint and mapping [40]. Systems analysis can help to clarify problems and provide a broader interpretation [41,42]. As an analytical method, the systems thinking approach adopts a causal path method to describe the contextual relationship of the component within systems. The identification of systems can help to foresee the behavioral tendency as well as performance over time, such as reinforcing growth or balancing control to specific standards.

Systems thinking identifies where an enterprise is located at an ecosystem. The innovation ecosystem model describes how the complex relationships among actors in the system come into being, where the common objective is to promote technological development and innovation [43]. A variety of innovation styles, such as open source, crowdsourcing, and service and user innovation, are based on this model and are referred to as open innovation [44]. The model contains two streams: first is separated economies, which includes the technology-driven R\&D economy and the market-driven economy, as these two are interdependent on each other and generate a cycle. While different scholars have different interpretations of the term ecosystem [45,46], such as industrial networks [47], social networks [48] and network embeddedness [49], the core thinking of these viewpoints emphasize co-existence among organizations. According to the definition given by Autio and Thomas [50], an innovation ecosystem is a linked network among organizations, including producers and users who create value through joint innovation. Interdependence and co-evolution are the important features of these two innovation ecosystems [21].

Two mainstream flows of knowledge can be observed from previous studies. The first mainstream is based on industrial innovation and technological transformation, which extend the contexts of innovation ecosystems and market ecosystems [51,52]. In this context, a large number of documents have proven that technological innovation and new business development are the driving force of market growth $[53,54]$. The business model driven by technological innovation develops and guides the progress and growth of a market, and the economic performance driven by such market growth encourages enterprises to further invest in technological innovation to enhance this positive cycle. The second type of mainstream research focuses on the resource-based theory to observe the competition and cooperation among organizations [55], and such research stresses how inter-organizational cooperation and cross-organizational boundaries shape themselves [56] and the competitive strategies of enterprises in the business ecosystem [52].

\subsection{The Structure and Feedback Loop of Innovation Ecosystem}

This study follows the trend of the first type of mainstream research to explore the context of a technology-driven innovation ecosystem. As an innovation ecosystem is a network of different actors, the ecosystem shows diversity $[50,57]$.

Four conceptual variables are identified as driving forces for innovative economies: (1) technological innovation; (2) development of new business; (3) market performance; (4) competitiveness of industrial clusters. Firstly, the concept of technological innovation includes investment in different technologies, as well as the relative costs of alternative technologies; secondly, the concept of the development of new business describes the link among technological innovation, the market, and business models; thirdly, market performance includes various concepts, such as market size, market potential, and economies of scale; fourthly, the competitiveness of industrial clusters includes the technological innovation and new business driven by the competitive advantages of industrial clusters. 
Among these conceptual variables, three main reinforcing feedback loops and their effects are identified. Firstly, R1 represents the development path of technological innovation, the competitiveness of industrial clusters, and economic performance. Technological innovation will drive the competitiveness of industrial clusters, and such increasing competitiveness will drive better economic performance and produce more investment in technological innovation, thus, generating a reinforcing feedback loop. Secondly, R2 represents the development path of innovation-driven new business, and focuses on the relationship between new business and market opportunities, rather than competition. Thirdly, R3 represents the reinforcing feedback path of new business development, where technological innovation drives the development of new business and the competitiveness of industrial clusters. This rising competitiveness promotes economic performance and attracts more investment in technological innovation to create reinforcing feedback. Conceptually, technological innovation is the driving force to strengthen technological development, new business development, and economic benefits; however, such a feedback system will not automatically sustain itself, as it is the organizational strategy guided by managers' strategic thinking that holds the key to the sustainable development of an ecosystem. Therefore, this study adds a fifth conceptual variable: strategic orientation, which aims at different organizational concepts, including customer demand [58], innovation [59], risk-taking [60], and organizational learning [61], as well as EO, IO, and MO. The impacts of different strategic orientations on system paths are further described, and the relationship among these important variables is described in the innovation ecosystem, as shown in Figure 1.

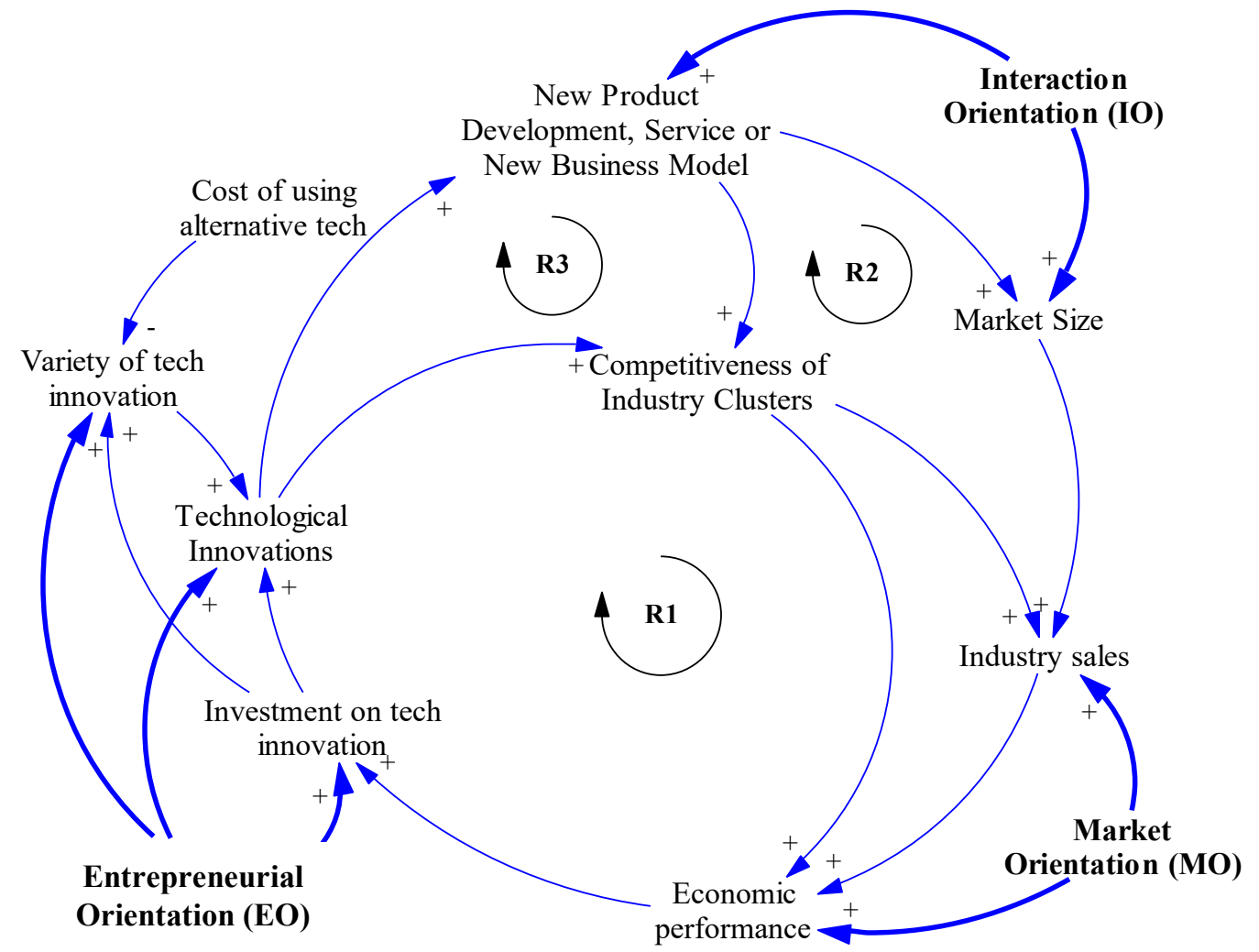

Figure 1. Strategic Orientation for Technology-driven Business Innovation Ecosystems.

\subsection{The Concepts of $M O, I O$, and $E O$}

MO is the implementation of market concepts, including market intelligence generation, generation dissemination, and responsiveness [62]. Intelligence generation involves the collection and analysis of information regarding customer behavior; generation dissemination is a sharing mechanism that allows the different departments of an organization to receive market intelligence; finally, responsiveness 
involves the use of available information to produce products that meet customer needs. Previous studies have shown that companies with better MO deliver better performance [6,7].

EO enables a company to be constantly ahead of its competitors and seize opportunities for innovation in an uncertain environment. EO includes innovativeness, proactiveness, and risk-taking [63]. Innovativeness refers to the application of new technologies to new products [64]; proactiveness indicates the quest for new opportunities that meet future customer needs; risk-taking shows the managers' view regarding investment in volatile industries. EO represents the decision-making, activities and practices of a company when entering a new market [65]. In other words, organizations regard EO as the innovator of a product market and take the initiative to engage in risky activities and eventually defeat competitors. Foxall [66] suggested that EO is a positive strategic orientation accompanied by high uncertainty and risk, which drives the development of new products. A large number of previous studies have discussed the relationship among EO, new product development [58], and new product performance [11,12,61,67,68].

Finally, IO represents the effectiveness of the interaction between organizations and individual customers, as well as the useful customer information obtained through such successful interactions [5]. According to IO, the successful innovation of an organization is based on its positive relationship with customers. Organizations can improve corporate performance by accumulating the knowledge of customers' preferences and needs [69]; therefore, the interactive model provides opportunities for companies to create value with individual customers, and thus, increase the mutual benefits [70]. Previous studies have conceptualized IO as a composite construct, including customer concept, interaction response capability, customer empowerment, and customer value management $[5,16]$, and these dimensions are considered to reflect the company's basic beliefs, processes, and practices [71]. Customer concept means that a company takes each individual customer into account when analyzing marketing and market reactions, deems the uniqueness of every customer as the starting point of all marketing activities, and focuses on the process of value co-creation; the interaction response capability reflects the capacity of an organization to respond quickly to heterogeneous customer demands; customer empowerment is the degree of value co-creation between customers and manufacturers in the interactive process; and finally, customer value management determines how capable a company is at dynamically evaluating customer value, and using such information for resource allocation [5]. Although both $\mathrm{MO}$ and $\mathrm{IO}$ focus on customers, they show different characteristics and the significance of activities for corporate value creation. $\mathrm{MO}$ advocates that value creation activities are the responsibility of companies, while IO advocates that value creation activities are jointly created by companies and customers. Table 1 presents more detailed descriptions of these concepts.

Table 1. Distinguishing Interaction, Market, and Entrepreneurial Orientations.

\begin{tabular}{|c|c|c|c|}
\hline Orientation & Interaction & Market & Entrepreneurial \\
\hline Concept & Customer & Marketing & Competitor \\
\hline Conceptualization & $\begin{array}{l}\text { Faith of organizations in } \\
\text { customers, interactive responsive } \\
\text { capability, and customer value } \\
\text { management }\end{array}$ & $\begin{array}{l}\text { Collection, publicity, and } \\
\text { responsiveness of market } \\
\text { intelligence by the departments of } \\
\text { an organization }\end{array}$ & $\begin{array}{c}\text { Process of corporate strategic } \\
\text { orientation that guides } \\
\text { decision-making }\end{array}$ \\
\hline Business philosophy & With the customer & For the customer & For the stakeholder \\
\hline Strategy & $\begin{array}{c}\text { Developing excellent capabilities } \\
\text { to attract, sustain, and cooperate } \\
\text { with valued customers }\end{array}$ & $\begin{array}{l}\text { Developing capabilities superior } \\
\text { to those of competitors to satisfy } \\
\text { customers, including better } \\
\text { products and services }\end{array}$ & $\begin{array}{l}\text { Developing better capabilities of } \\
\text { creating, discovering, and seizing } \\
\text { opportunities than those of } \\
\text { competitors }\end{array}$ \\
\hline Behavior & $\begin{array}{l}>\quad \text { Value co-creation with } \\
\text { every customer } \\
>\quad \text { Solving problems together } \\
\text { with customers } \\
>\quad \text { More } \\
\text { two-way communication }\end{array}$ & $\begin{array}{l}\text { Conveying good } \\
\text { customer value } \\
\text { Mainly } \\
\text { one-way communication }\end{array}$ & $\begin{array}{ll} & \text { Engaging in creative } \\
\text { activities through new } & \text { product innovation } \\
>\quad & \text { Technological leader } \\
>\quad & \text { Introducing new products or } \\
\text { services for future needs } \\
\text { earlier than competitors }\end{array}$ \\
\hline
\end{tabular}


The relationship between $\mathrm{MO}$ and $\mathrm{EO}$ has been discussed extensively in previous articles [72,73]; for example, some studies have considered $\mathrm{MO}$ is an antecedent variable of EO [74,75] or there is a high correlation between these two [72,76,77]. While both are important to the company, few studies include IO for comprehensive performance discussion. This study focuses on the role of three strategic orientations in the innovation ecosystem, and explores the relationship between strategic orientation and corporate performance in a complete context.

\section{Research Method}

\subsection{Case selection and Description}

This study compares and summarizes different companies with the multiple-cases method, where Taiwanese enterprises are taken as the research subject. According to the ranking of the 2018 Global Competitiveness Report by World Economic Forum, Taiwan was described as a "super innovator" in terms of innovation capability as one of four economies, including Germany, Switzerland, and the U.S. The ranking of Taiwan shows that the industrial clusters and innovation ecosystem of Taiwanese vendors is so unique that it deserves further discussion. In the case selection process, this study was supported by the Ministry of Science and Technology and the National Applied Research Laboratories (NARLabs), which is important governmental agency and research insititute in Taiwan's technological development and future technological research. According to the research purpose, this study selected three typical Taiwanese high-tech enterprises from over 50 candidate enterprises as the research subjects. The number of cases selected for this study follows the suggestion of Eisenhardt [78] to improve research validity. These three companies are pro-active in product $R \& D$ and deliver significant market performance. In addition, they have strong personal contact for data acquisition, which is conducive to accumulating diversified and real cases. Therefore, this study describes the dynamic processes of the innovative models and the market development of the three cases, and determines the relationship between strategic orientation and the above-mentioned two cases to build a theoretical model [79].

This study follows three criteria in case selection [80]: (1) the research subjects should make certain contributions to scientific, technological, and market innovations; (2) the dynamic development of scientific and technological innovations and market developments can be observed; (3) the strategic orientation of the research subjects in different stages of the innovation ecosystem can be observed. Following the above criteria, this study presents, analyzes, compares, and summarizes the innovation ecosystems of the three cases. The following is a brief introduction of the companies and their development processes, and the basic data are incorporated into Table 2.

Table 2. Basic Information of Case Companies.

\begin{tabular}{|c|c|c|c|}
\hline Case Company & Imager-37 & Brogent Technologies & $\begin{array}{l}\text { United Orthopedic } \\
\text { Corporation }\end{array}$ \\
\hline Time of establishment & 1971 & 2001 & 1993 \\
\hline Products/services & $\begin{array}{l}\text { Foam products, such as mattresses, } \\
\text { pillows, office chairs, etc. }\end{array}$ & $\begin{array}{l}\text { Research and development of } \\
\text { software and hardware, } \\
\text { integration of manufacturing and } \\
\text { system, design, planning, and } \\
\text { construction of new media } \\
\text { somatosensory theatre. }\end{array}$ & $\begin{array}{l}\text { Orthopedic implants } \\
\text { (artificial joints) and } \\
\text { related surgical } \\
\text { instruments }\end{array}$ \\
\hline Product type & Bedding industry & Information industry & $\begin{array}{l}\text { Medical materials } \\
\text { industry }\end{array}$ \\
\hline Sales base & $\begin{array}{c}\text { Taiwan's } 25 \text { department store } \\
\text { counters }\end{array}$ & $\begin{array}{l}\text { Create various new-generation, } \\
\text { new media somatosensory } \\
\text { amusement facilities for theme } \\
\text { parks or large-scale recreational } \\
\text { activities }\end{array}$ & $\begin{array}{l}\text { Selling to more than } 38 \\
\text { countries in Europe, the } \\
\text { Americas, Asia, and } \\
\text { Africa. }\end{array}$ \\
\hline Record of recent awards & $\begin{array}{l}6 \text { times winning Taiwan's } \\
\text { Excellent Awards; } 5 \text { times of SNQ } \\
\text { Biotechnology Medical Label }\end{array}$ & $\begin{array}{l}2017 \text { Eurostar Awards for Europe's } \\
\text { Best New Ride in Theme Parks }\end{array}$ & $\begin{array}{l}2017 \text { Taipei Biotech } \\
\text { Award International } \\
\text { Leap Forward Award }\end{array}$ \\
\hline
\end{tabular}




\section{(1) Imager-37}

Imager-37 was founded in 1971 and started with foam production. Its initial products include synthetic sponges for the locomotive industry, integrally molded car interiors, rigid sponges for refrigeration equipment, and spray-painted molded sponges for toys. The original semi-rigid self-contained foam armrest from 1980 drove the vigorous development of OA office furniture in Taiwan. Since 2000, it has been developing its own bedding brand, which has gradually transformed and developed products in the field of intelligent life care. Material science and technology are combined with physiological sensing technology, and the IoT (Internet of Things) and big data analysis are being used to develop a series of mattress systems and related commodities, as applied to home-based long-term care and intelligent medical care.

(2) Brogent Technologies

Brogent Technologies was founded in 2001, and its main product is "i-Ride flying theater" with a unique global six-axis platform technology, which has created immersive experiences and is sold to all major theme parks, museums, exhibition halls, and shopping malls around the world. When Brogent Technologies developed the flying theatre, it not only saw the advantages of its own hardware technology, but also the shortcomings of its software and content. In recent years, it has cooperated with Taiwan's universities and colleges through "Kodansha" (Giant Killing), which intends to acquire high value and high-quality IP, and strengthen the integration of software and hardware to develop more competitive innovative products.

(3) United Orthopedic Corporation

Founded in 1993, and starting from agency and contract manufacturing, it has now become the only bone material company in Asia capable of engaging in special processes, such as upstream forging, casting, and downstream plasma spraying of orthopedic equipment, titanium bead sintering, etc. United Orthopedic is a product market that meets the needs of Asian human body and life styles, as it refined its product manufacturing, and actively constructed a local cooperation network (dealers, doctors) to quickly enter the market during the transformation process. Moreover, it supports multinational clinical research and has established a platform for cooperation and communication among multinational orthopedic doctors, where the aim is to grow together with many partners, while creating a "one-stop service" of research and development, design, manufacture, and marketing.

\subsection{Data Gathering and Analysis Procedures}

The data sources of this study include secondary data collection and interviews. The secondary data include news reports and the official websites of the three companies. In terms of interviews, this study carried out four interviews with the senior management and groups of the case companies from February to April, 2019, and interviewees included deputy general managers, directors, and business managers. Each interview lasted for approximately 30-60 min, and was recorded for transcription after the interview. Interview questions are focused on questionnaires and include three types: (1) business history of enterprise, exploring the history and current situation of company development; (2) the relationship between technological innovation and market development, such as how market performance drives technological innovation, the driving force of technological innovation, and how new business develops; (3) strategic orientation of companies. However, these interview questions are adjusted according to what the interviewer response [81].

In terms of data validation, this study adopts qualitative research credibility criterion, as advocated by Lincoln and Guba [82], to ensure the credibility of this study. Triangulation is conducted by comparing and summarizing multilevel data types, where the differences in data sources are used to explain whether the constructed results are different, as shown in Table 3. Later, according to the principles proposed by Bogdam and Bi [83], data are transcribed by focusing on dialogue reconstruction, the description of external environments, and the presentation of events, which are followed by coding analysis. During the interviews and secondary data review, this study used open coding to collect and capture the views of respondents. In this stage, due to the divergence of data, this study rigorously and 
repetitively reviewed the data [84], in order to determine and classify suitable codes for the research topics, and then, mapped them with theoretical models.

Table 3. Collection of qualitative data.

\begin{tabular}{cccccc}
\hline $\begin{array}{c}\text { Data } \\
\text { Collection }\end{array}$ & Category & Position & Number & $\begin{array}{c}\text { Time/Location } \\
\text { of Interview }\end{array}$ & Duration \\
\hline $\begin{array}{c}\text { Formal } \\
\text { interview }\end{array}$ & $\begin{array}{c}\text { Decision-makers } \\
\text { Executives }\end{array}$ & $\begin{array}{c}\text { Deputy GMs, directors } \\
\text { Engineers, sale personnel }\end{array}$ & 5 & $\begin{array}{c}\text { Company's } \\
\text { meeting room }\end{array}$ & 10 \\
$\begin{array}{c}\text { Secondary data } \\
\text { collection }\end{array}$ & Books, journal articles, web page information, news, and conference records & 30 \\
& & Total & 55 \\
\hline
\end{tabular}

Note: Executives include the participants and logistic personnel of volunteer clinical activities.

\section{Research Finding}

This study explains the innovation ecosystems of three case companies, describes the development context of the new business of the case companies, and finally, focuses on how different strategic orientations play a reinforcing role in the innovation ecosystem. The findings are shown, as follows:

\subsection{Description of an Innovation Ecosystem}

Innovation ecosystems advocate that investment in technological innovation will drive technological innovation, and subsequently, the development of new business and competitiveness of industrial clusters, which ultimately results in rising economic performance, which will become the driving force of technological innovation and create a positive cycle. The three cases in this study all show the same trajectory of innovative development, as shown in Figure 2.

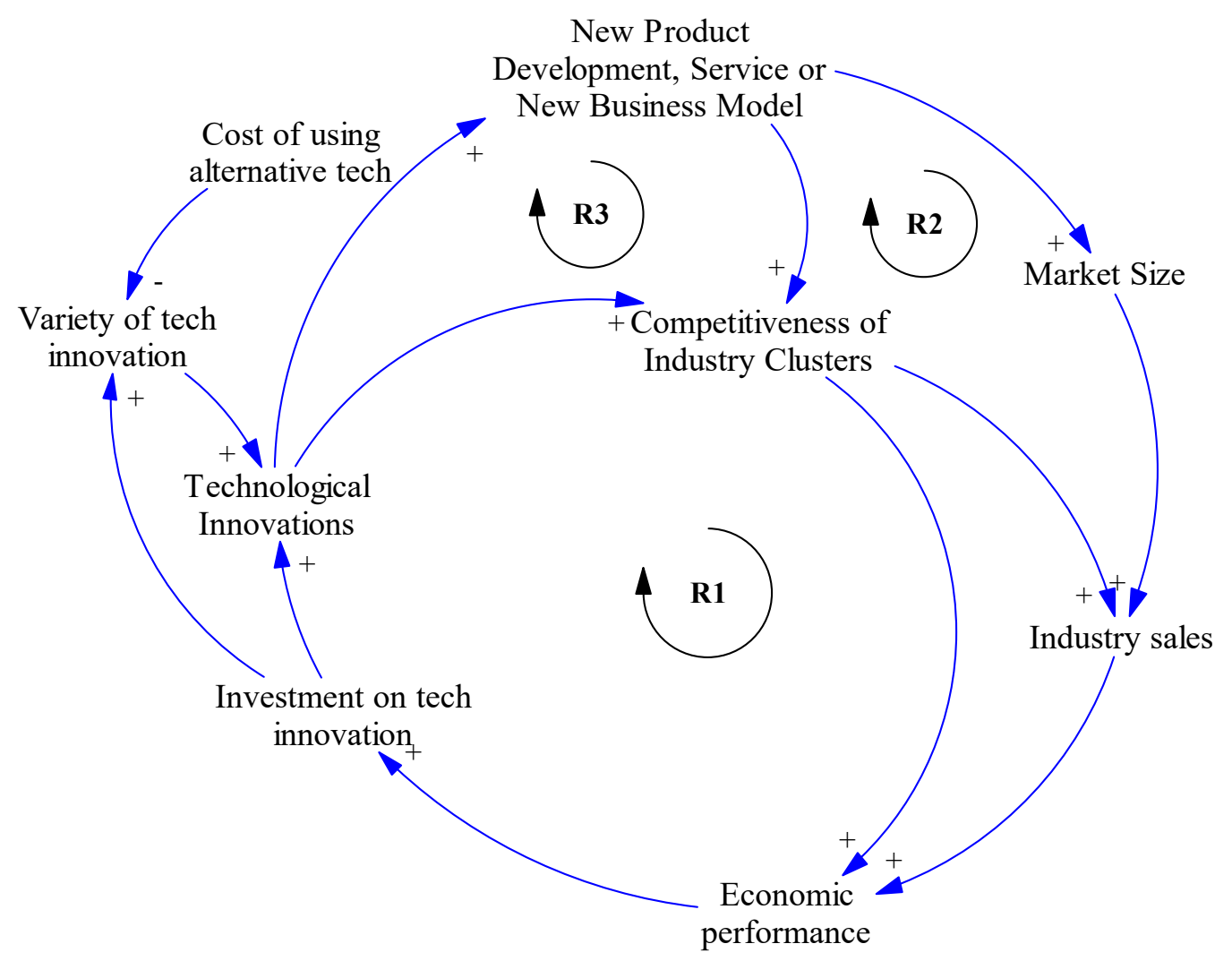

Figure 2. Technology-driven Business Innovation Ecosystems. 
Imager-37 specialized in the production of foamed cotton-related commodities in its early stage, thus, mold foaming was the core technology of Imager-37. With this technology, Imager-37 customized products by developing different ergonomic molds that fit ergonomically. These products were mostly applied to automobile components in the early stage; later, as automobile components were internalized by automobile manufacturers, the traditional foaming technology was elevated to the industry of high-precision medical materials, and was applied to bedding items, such as mattresses, cushions, and pillows. Currently, the focus of Imager-37 has diverted from the brand bedding industry to intelligent health care and technological nursing, and its products include numerous innovative applications, such as sleep medicine, technological aids, and mental retardation care.

Brogent Technologies initially focused on website design, where the design of broadband service content was its major service. Later, it stepped into the mobile software business and made a breakthrough in technology by transplanting the compressed format of some videos and audios to mobile devices, and thus, became a rare developer of mobile device multimedia technology in Taiwan. The company's strength in software was also noticed by amusement manufacturers, and they asked the company to develop amusement equipment, thus, it has gradually been moving towards somatosensory amusement facilities. Nowadays, according to the customer needs of theme parks or large entertainment centers, the company uses its core technology, which is coupled with the novel 3D somatosensory simulation technology, to create a variety of new-generation and new-media somatosensory amusement facilities.

The United Orthopedic Corporation was merely a trading company, which acted as an agent for orthopedic equipment in its infancy. While products sold, suggestions given by customers for products were often heard. However, limited by market size, the original factory failed to differentiate the products that target the Taiwanese market. Thus, President Lin of the company established Joint in 1993 to manufacture various types of knee joints, hip joints, and accessories for medical treatment. To date, the company has won numerous awards and new patents both at home and abroad, including product group and capabilities in R\&D and design.

Innovation ecosystems advocate that technological innovation will exert positive impact on new business development; however, this study finds that technological innovation first drives the development of new products, then generates new business development, and finally, extends to the development of new markets. This trajectory is observed in the three case companies. For example, through R\&D, Imager-37 changed the hardness of its materials through a slight change of temperature, and developed memory foam with temperature-sensitive pressure relief; this product was first applied to pillows, and was appreciated by Wang Yung-ching, ex-president of the Formosa Plastic Group. Since then, the case company has developed bedding-related products, such as mattresses and cushions, and these products have gradually merged as a new business group with customized products in line with the market. Brogent Technologies was awarded an order for the Hunei amusement park in 2007 by virtue of its R\&D capability in software and hardware, and contributed to completing the "Flying over Taiwan" sensory simulation equipment. Brogent was the second global manufacturer following Disney to master the technology of "somatosensory simulation equipment" combined with video and audio, and to date, it has stepped into the sector of sensory entertainment equipment. Today, the company is able to provide customized somatosensory experiences for customers of different countries. Households create customized body feeling experience. The United Orthopedic Corporation started with OEM, and over the years, it has provided artificial joint manufacturing services for over 38 medical markets in Europe, America, Asia, and Africa. However, the body shapes of Asians differ from that of Europeans and Americans, thus, existing product specifications do not fit the shape of Asians. Therefore, this company develops products for the artificial joints of Asians, and their business has evolved to a complete orthopedic business. In addition to providing products with specifications required by customers with special size, the Asia-based competitive strategy of the company helps it earn the name of the orthopedic company that knows Asian bodies the best. 


\subsection{The Role of EO in the Innovation Ecosystem: United Orthopedic Corporation}

The business philosophy of the United Orthopedic Corporation fully reflects the significance of entrepreneurial orientation. Such thinking exerts a positive effect on the company's investment in technological innovation, and promotes the development of new products, which is reflected in its revenue of recent years, as shown in Figure 3.

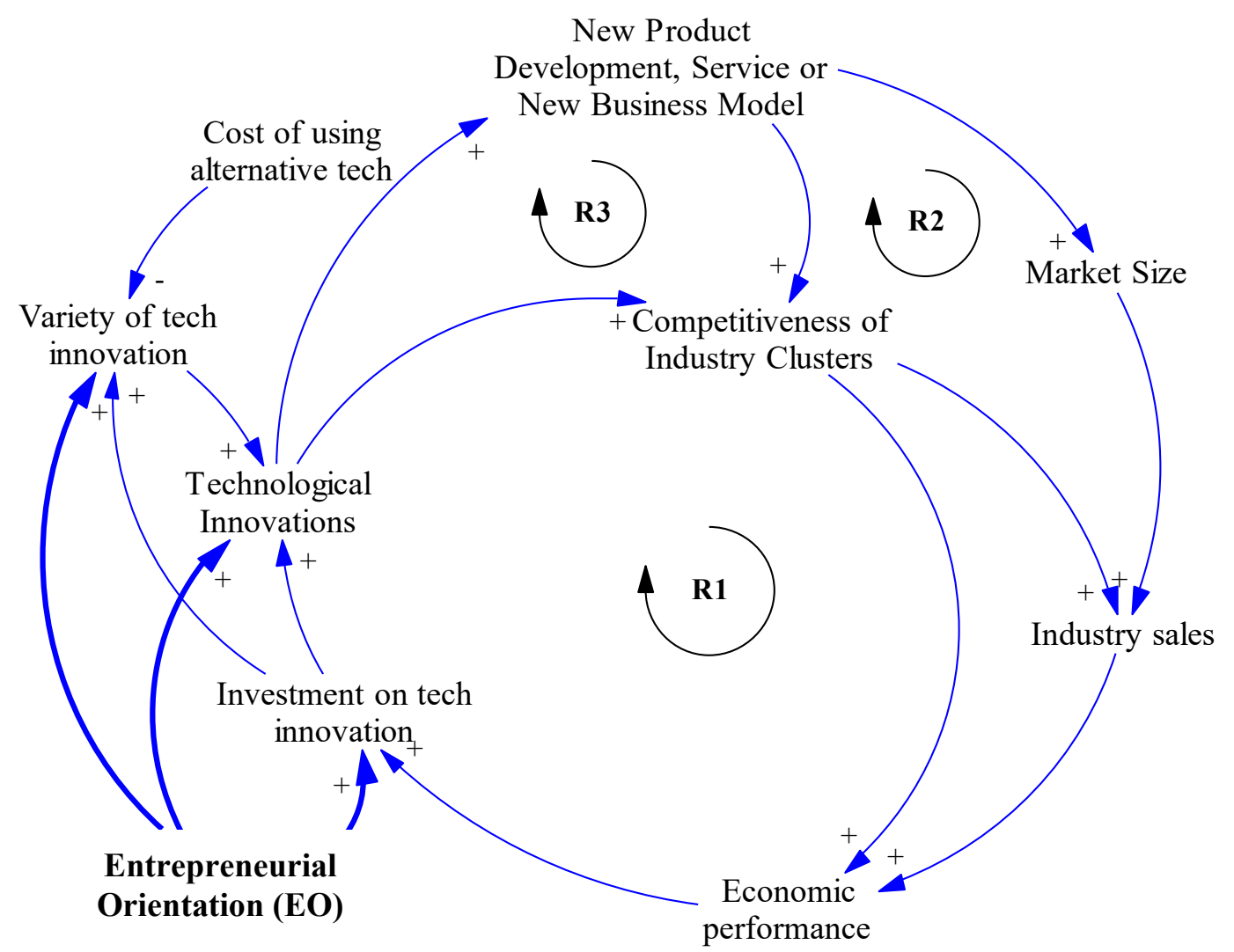

Figure 3. Entrepreneurial Orientation for Technology-driven Business Innovation Ecosystems.

In terms of motivation for innovation, one third of nearly 400 employees of Taiwanese companies are dedicated to $R \& D$, design, and manufacturing engineering, and the percentage of the $R \& D$ expenditures of annual turnover is over $10 \%$. This company has won a large number of awards and new patents at home and abroad, indicating that the company is able to compete with global major manufacturers, such as Johnson \& Johnson and Stryker. The initiative of this company can be observed from the design thinking of its products. The average life span of artificial joints for the human body is only 15 years; however, due to the increasing average life expectancy of people, some patients may need to remove and replace old artificial joints with new ones. In this case, it is very important to retain the original bone proportion to facilitate the attachment of artificial bones; therefore, the company provides products and components of different scales, and even develops a variety of tools for bone reduction. These new products help doctors accurately install artificial joints; however, Western manufacturers fail to take this into consideration. Regarding risk-taking, the case company takes the niche market as its market competition strategy, which has higher risks, such as providing special artificial joints for patients with bone cancer, and such risk-taking is indicative of the company's effort to meet the needs of special patients. Meanwhile, the company boasts the advantage of vertical integration in product processes, and masters all processes ranging from raw metal materials to finished products, while most major Western factories only master the core technology and entrust manufacturing to other manufacturers. This process reflects the company's requirement for product quality, and explains why the company is so energetic in technological innovation and R\&D, as shown in Table 4. 
Table 4. Code of entrepreneurial orientation.

\begin{tabular}{|c|c|c|}
\hline Factors & nalysis & Code \\
\hline \multirow{3}{*}{$\begin{array}{l}\text { Entrepreneurial } \\
\text { orientation }(\mathrm{EO})\end{array}$} & Innovativeness & $\begin{array}{l}\text { - The number of R\&D, design, and process engineers } \\
\text { accounts for } 1 / 3 \text { of the total number of employees in } \\
\text { Taiwanese companies } \\
\text { The percentage of R\&D expenditures is more than } 10 \% \text { of } \\
\text { the turnovers. }\end{array}$ \\
\hline & Proactiveness & - Developing products and components of multiple sizes \\
\hline & Risk-taking & $\begin{array}{l}\text { - Focusing on the niche market of Taiwan } \\
\text { - Top1 of Asia in the vertical integration of the processes of } \\
\text { all products }\end{array}$ \\
\hline
\end{tabular}

\subsection{The Role of IO in the Innovation Ecosystem: Imager-37}

Imager-37's business philosophy can fully reflect the significance of interaction orientation, and such thinking has positive reinforcing effect on the company in new product development, as shown in Figure 4.

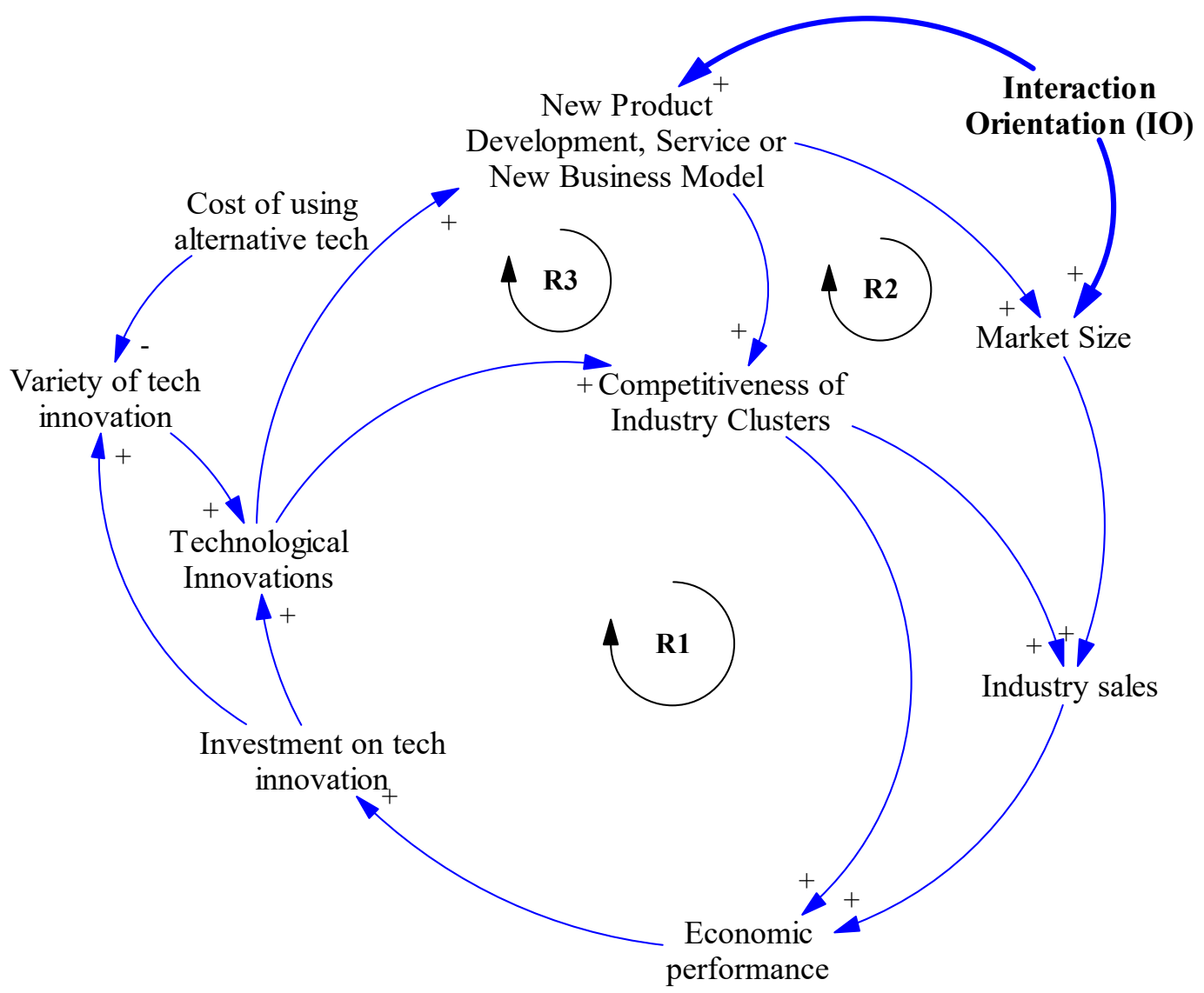

Figure 4. Interaction Orientation for Technology-driven Business Innovation Ecosystems.

According to the sub-dimension of interaction orientation, Imager-37 regards individual customers as the market-segregated unit. This company can provide customized services of different sizes or specialties for different customer needs. For example, customers can adjust the thickness of mattresses, and the company provides pillows of different series for customers' different sleeping postures; some products are even capable of alleviating snoring. In terms of interactive responsiveness, the products 
of the on-bed care system simultaneously satisfy the needs of different roles for users. This system allows nursing personnel to be informed of what is happening to their patients in real time without wearing any device, and provides a three-stage early warning system against falling down (sitting up, sitting on the bed edge, leaving bed). Medical and nursing personnel can link electronic signboards with a nursing mattress system or use the mobile device APP to grasp the information of patients in bed, and address abnormal events. The mattress is also capable of posture identification. For patients at high risk of bedsores, the mattress can remind the nursing personnel of turning the patients over and patting their back on a regular basis to avoid the risk of bedsores caused by negligent work. The information of bedridden patients, such as sleep quality reports, can be obtained through mobile phones. Mattress can also distribute weight and pressure equally to prevent pressure ulcers. Therefore, the company's interactive responsiveness is reflected in its sleep health management and long-distance home care. In terms of customer empowerment, the company will observe the sleep quality of patients or recipients through clinical tests in cooperation with hospitals, record the information of contact stress, and create product value jointly with users in the process of developing products. Finally, regarding customer value management, the Internet of Things and big data analysis are used to send the data collected by sensors into the machine learning software, which indicates the corresponding data of patients lying in bed for the development of long-term intelligent medical products, as shown in Table 5. This case shows that interaction orientation is the reason why the case company can step into intelligent health care and successfully develop new businesses.

Table 5. Code of interaction orientation.

\begin{tabular}{|c|c|c|}
\hline Fact & rs of Analysis & Code \\
\hline \multirow{4}{*}{$\begin{array}{c}\text { Interaction } \\
\text { orientation (IO) }\end{array}$} & Customer concept & $\begin{array}{l}\text { - Provision of customized services or special sizes for } \\
\text { different customer needs } \\
\text { - } \quad \text { Differentiated product functions }\end{array}$ \\
\hline & $\begin{array}{l}\text { Interaction response } \\
\text { capability }\end{array}$ & $\begin{array}{l}\text { - Improvement of care by nursing personnel } \\
\text { - Prevention of sequelae, as caused by being confined } \\
\text { to bed }\end{array}$ \\
\hline & Customer empowerment & - Collection of numerous clinical data \\
\hline & $\begin{array}{l}\text { Customer value } \\
\text { management }\end{array}$ & $\begin{array}{l}\text { - Use of the Internet of Things and big data analysis to } \\
\text { develop mattress systems and related products of } \\
\text { intelligent health care }\end{array}$ \\
\hline
\end{tabular}

\subsection{The Role of MO in the Innovation Ecosystem: Brogent Technologies}

The business philosophy of Brogent Technologies fully reflects the significance of market orientation, and such thinking has positive reinforcing effect on the company's efforts to expand the market scale of its products, as shown in Figure 5. 


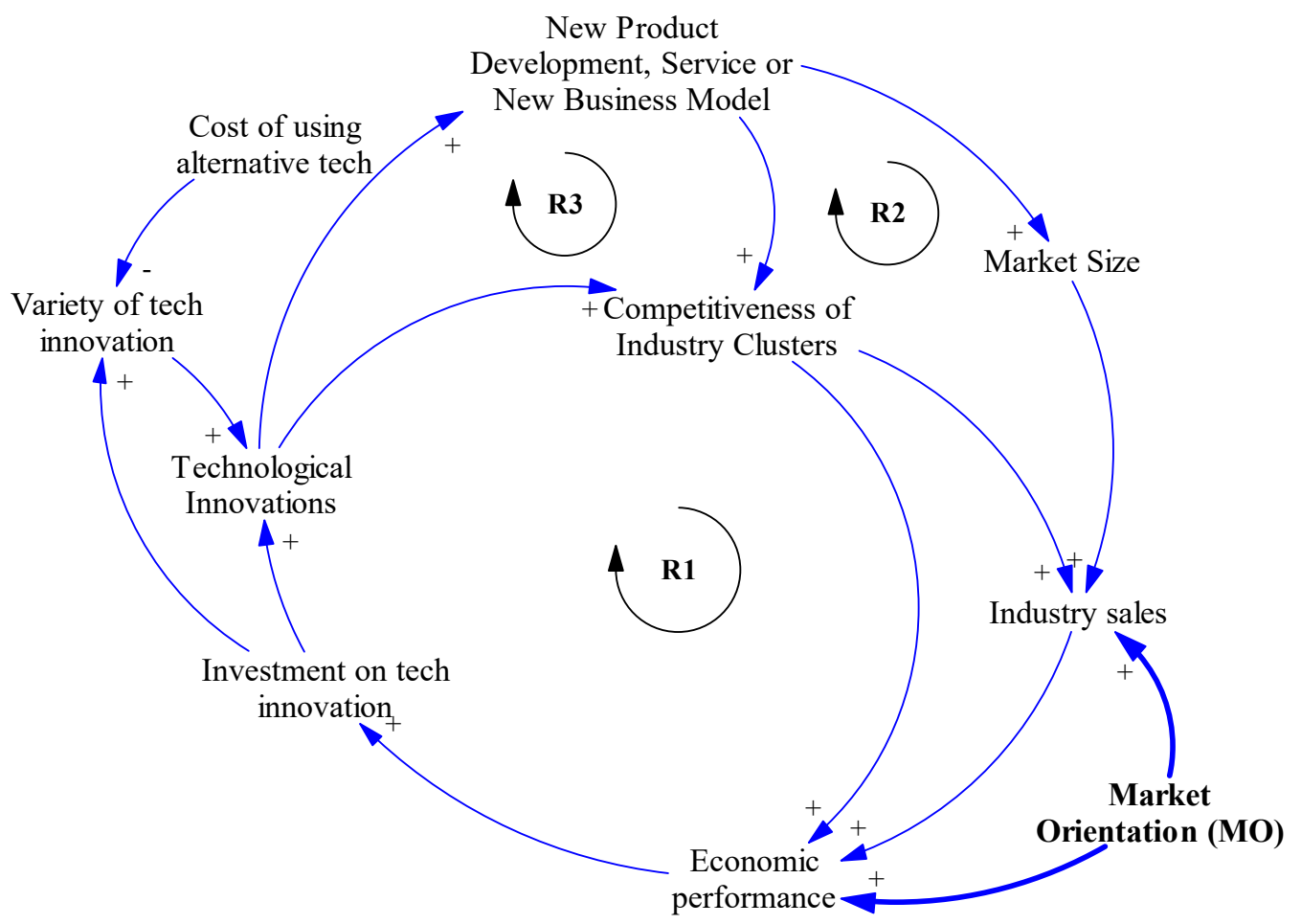

Figure 5. Market Orientation for Technology-driven Business Innovation Ecosystems.

According to the sub-dimension of market orientation, the company collects market intelligence through market research and exhibitions, such as the exhibition of IAAPA (International Association of Amusement Parks and Attractions), annual exhibitions of theme park and equipment, and the Digital Entertainment Media Trend Forum. Through these exhibitions, the company can be more widely known and obtain the information of its competitors. Graham Quirk, the Mayor of Brisbane (Australia), even invited the company to visit Australia after the Global Harbor Cities Forum in 2016, aiming to promote the local investment and market intelligence generation of the company. Regarding external publicity, the company carries out cross-industry cooperation and holds somatosensory game competitions to present the company's products to the market. For example, in 2015, the company signed a MOU with Kodansha, Japan's largest publisher, in order to expand its bilateral cross-industry cooperation in the entertainment market; while internally, the company holds cross-department meetings to convey market information to the members of the organization. Therefore, the company can be highly responsive to factory demands and reflect market performance. For example, the LEGO MOVIE Masters of Flight (a flying theatre), as co-created by LEGO LAND and the company, will open in the spring of 2019 at LEGO LAND in the state of Florida, and the company's unique technology-patented large amusement facilities can be seen in EUROPA PARK, Germany's largest theme amusement park, and Ferrari Land in Spain, as shown in Table 6. This serves as testimony to the impact of market-oriented mentality on the market size of the company. 
Table 6. Code of market orientation.

\begin{tabular}{|c|c|c|}
\hline & ctors of Analysis & Code \\
\hline \multirow{3}{*}{$\begin{array}{l}\text { Market-orientation } \\
\quad(\mathrm{MO})\end{array}$} & Market intelligence Generation & $\begin{array}{l}\text { - } \quad \text { Market investigation } \\
\text { - } \quad \text { Participation in exhibitions and seminars }\end{array}$ \\
\hline & Market intelligence Dissemination & $\begin{array}{ll}\text { - } & \text { Cross-industry cooperation } \\
\text { - } & \text { Holding activities } \\
\text { - } & \text { Formal and informal meetings }\end{array}$ \\
\hline & Market intelligence Responsiveness & - $\quad$ New experience tourism \\
\hline
\end{tabular}

\section{Discussion}

\subsection{Theoretical Contributions}

This study selects three representative case companies from a nation-wide database of the Ministry of Science and Technology in Taiwan to observe the impacts of different strategic orientations on the innovation ecosystem at the corporate level. By comparing the companies of different countries selected as subjects for previous studies, this study identifies how the meanings of innovation ecosystems vary from one country to another. For example, Rao and Jimenez [29] observed the innovation ecosystems of Apple and Google, which both digitally link the elements of innovation ecosystems. According to their study, consumers, users, and developers can foster synergy on online platforms, and generate network externalities that increase the value of software and hardware innovation. Other studies also found that some innovation ecosystems are university-based, thus, universities are regarded as a source of innovation. The university-enterprise relationship plays an important role in technological success, such as the Technical University of Madrid [85,86]. In Finland, the government integrates resources to build an innovation ecosystem powered by national technological policies, and boosts the close collaboration between industry and university through investments in education, $R \& D$, corporate technology innovation, entrepreneurship, and corporate export capability enhancement. Many well-known global startups, such as RAVIO Mobile and PAPTIC, have sprung up in Finland, which indicates the positive impact of government support on innovation ecosystems [87]. Taiwan features a high-tech centered SME ecosystem; in an industrial environment dominated by small and medium-sized enterprises, only enterprises with critical strategic thinking and enhanced ability can drive the development of the ecosystem [87]. This study further finds that market orientation, interaction orientation, and entrepreneurial orientation can generate a positive reinforcing causal loop on the overall innovation ecosystem.

More specifically, when an organization has market orientation, it means that the organization has market intelligence and responds to it [88], and such response will deliver superior customer value and more two-way communication, which will have positive reinforcing effect on the development of new products and new businesses. Interaction orientation represents the belief in customers, value co-creation with customers, and interaction with customers to solve common problems jointly. Therefore, market orientation has positive reinforcing effect on the development of new products and businesses, as well as technological innovation. Entrepreneurial orientation will increase the exploratory activities of enterprises $[61,88,89]$, and such orientation emphasizes the process of strategic decision-making and the stakeholder-centered business philosophy. It also attaches importance to risky investments in resources of unknown environments, or the introduction of new products/services to meet customers' future needs, thereby, exerting positive reinforcing effect on technological innovation and investment in technological innovation.

Further, this study also finds that the development of new businesses should be divided into phases, such as Mosey's [90] view on new to market products, meaning new product development and new market development are two elements of technological innovation, new business development, 
and market size. Technological innovation will have positive impact on the development of new products, and new businesses will not develop until the performance of new product developments are improved (e.g., product novelty and speed of product development). The development of new businesses must be in line with the market by collecting information on customers and competitors, in order that products and services can effectively meet customer needs, indicating that the company is starting to develop a new market.

In summary, this study contributes to the literature addressing the role of strategic orientation in innovation ecosystem literature by developing and empirically testing a theoretical framework informed by systems thinking.

\subsection{Managerial Implications}

In practice, understanding the strategic orientations of an enterprise is critical to the impact of its innovative ecosystem. This study proposes the following suggestions for business managers. First, companies must develop market-oriented thinking, as market orientation can produce a positive reinforcing effect on industry sales and economic performance. If a company focuses on boosting its economic performance, it must have access to marketing intelligence, and establish internal and external communication mechanisms, in order that intelligence can be fully understood internally and disseminated within the enterprise, thus, enabling the company to be responsive to market demands. Therefore, managers must be sensitive to the market, and be responsive through internal communication and coordination.

Second, when an enterprise fosters interaction-oriented thinking, it will have a positive reinforcing effect on the development of new products, services, and business models. Therefore, an enterprise must understand its consumers, allow them to be part of product development, and adopt customer value management methods to interact with consumers, thus, tightening the link between new product development and the market.

Finally, when an enterprise develops entrepreneurial orientation, it contributes to continuous investment in technological innovation; therefore, enterprises must foster the proactive innovation spirit and dare to take risks. Enterprises can apply the results of this study as a map for an innovation ecosystem model to understand how different kinds of strategic thinking impact the link between innovation activities and market activities.

\subsection{Limitation and Future Research Direction}

This study explores the innovation ecosystems of three case companies at the corporate-level, however, companies must develop various capabilities, such as marketing capabilities, R\&D, information technological capabilities, and internal and external communication capabilities to maintain balance in its ecosystem. Therefore, future research can probe into the impact of corporate capabilities on innovation ecosystems [91]. In addition, this study only takes the driving force of technologies into account, thus, future studies can focus on the impact of non-technological elements (such as strategy, culture, and institution) on innovation ecosystems [92].

Author Contributions: Conceptualization, M.-R.Y., T.-K.Y.; Funding acquisition, M.-R.Y.; Investigation, T.-K.Y., M.-R.Y.; Methodology, M.-R.Y., T.-K.Y.; Project administration, T.-K.Y.; Resources, M.-R.Y.; Supervision, M.-R.Y.; Validation, T.-K.Y. and M.-R.Y.; Visualization, T.-K.Y., M.-R.Y.; Writing-original draft, T.-K.Y.; Writing一review \& editing, M.-R.Y.

Funding: This research was funded by Ministry of Science and Technology, Taiwan, grant number MOST 106-2221-E-034-004-MY2 and MOST 107-2622-H-034-001-CC3.

Acknowledgments: This research was supported by grants from the Ministry of Science and Technology in Taiwan. Our appreciations are extended to Dr. Kuo-Ming Chien for helping the case investigation and empirical study.

Conflicts of Interest: The authors declare no conflict of interest. 


\section{References}

1. Kim, J.; Yoo, J. The effects of entrepreneurial orientation and environmental uncertainty on Korean technology firms' R\&D investment. J. Open Innov. Technol. Mark. Complex. 2019, 5, 29.

2. Arunachalam, S.; Ramaswami, S.; Herrmann, P.; Walker, D. Innovation pathway to profitability: The role of entrepreneurial orientation and marketing capabilities. J. Acad. Mark. Sci. 2018, 46, 1-23.

3. Avlonitis, G.; Salavou, H. Entrepreneurial orientation of SMEs, product innovativeness, and performance. J. Bus. Res. 2007, 60, 566-575. [CrossRef]

4. Dobni, C.B.; Luffman, G. Determining the scope and impact of market orientation profiles on strategy implementation and performance. Strateg. Manag. J. 2003, 24, 577-585. [CrossRef]

5. Ramani, G.; Kumar, V. Interaction orientation and firm performance. J. Mark. 2008, 72, 27-45. [CrossRef]

6. Hult, G.T.; Ketchen, D.J., Jr. Does market orientation matter? A test of the relationship between positional advantage and performance. Strateg. Manag. J. 2001, 22, 899-906. [CrossRef]

7. Jaworski, B.J.; Kohli, A.K. Market orientation: Antecedents and consequences. J. Mark. 1993, 57, 53-70. [CrossRef]

8. Bonner, J.M.; Walker, O.C., Jr. Selecting influential business-to-business customers in new product development: Relational Embeddedness and knowledge heterogeneity considerations. J. Prod. Innov. Manag. 2004, 21, 155-169. [CrossRef]

9. Carbonell, P.; Rodriguez-Escudero, A.I.; Pujari, D. Customer involvement in new service development: An examination of antecedents and outcomes. J. Prod. Innov. Manag. 2009, 26, 536-550. [CrossRef]

10. Lim, S.; Ribeiro, D.; Lee, S.M. Factors affecting the performance of entrepreneurial service firms. Serv. Ind. J. 2008, 28, 1003-1013. [CrossRef]

11. Boso, N.; Cadogan, J.; Story, V. Complementary effect of entrepreneurial and market orientations on export new product success under differing levels of competitive intensity and financial capital. Int. Bus. Rev. 2012, 21, 667-681. [CrossRef]

12. Fernández-Mesa, A.; Alegre, J. Entrepreneurial orientation and export intensity: Examining the interplay of organizational learning and innovation. Int. Bus. Rev. 2015, 24, 148-156. [CrossRef]

13. Moore, J.F. Predators and prey: A new ecology of competition. Harvard Bus. Rev. 1993, 71, 75-86.

14. Chesbrough, H. Open innovation: The New Imperative for Creating and Profiting from Technology; Harvard Business Press: Brighton, MA, USA, 2003.

15. Li, Y.R. The technological roadmap of Cisco's business ecosystem. Technovation 2009, 29, 379-386. [CrossRef]

16. Chen, Y.C.; Li, P.C.; Evans, K.R. Effects of interaction and entrepreneurial orientation on organizational performance: Insights into market driven and market driving. Ind. Mark. Manag. 2012, 41, 1019-1034. [CrossRef]

17. Liu, G.; Rong, K. The nature of the co-evolutionary process: Complex product development in the mobile computing industry's business ecosystem. Group Org. Manag. 2015, 40, 809-842. [CrossRef]

18. Ireland, R.D.; Hitt, M.A.; Vaidyanath, D. Alliance management as a source of competitive advantage. J. Manag. 2002, 28, 413-446. [CrossRef]

19. Kohtamaki, M.; Rabetin, R.; Möller, K. Alliance capabilities: A review and future research directions. Ind. Mark. Manag. 2018, 68, 188-201. [CrossRef]

20. Dougherty, D. Taking advantage of emergence for complex innovation ecosystems. J. Open Innov. Technol. Mark. Complex. 2017, 3, 14. [CrossRef]

21. Adner, R.; Kapoor, R. Value creation in innovation ecosystems: How the structure of technological interdependence affects firm performance in new technology generations. Strateg. Manag. J. 2010, 31, 306-333. [CrossRef]

22. Chen, Y.; Rong, K.; Xue, L.; Luo, L. Evolution of collaborative innovation network in China's wind turbine manufacturing industry. Int. J. Technol. Manag. 2014, 65, 262-299. [CrossRef]

23. Rasiah, R.; Kong, X.; Lin, Y. Innovation and learning in the integrated circuits industry in Taiwan and China. J. Asia Pac. Econ. 2010, 15, 225-246. [CrossRef]

24. Tushman, M.L.; Anderson, P. Technological discontinuities and organizational environments. Admin. Sci. Quart. 1986, 31, 439-465. [CrossRef]

25. Dess, G.G.; Pickens, J.C. Changing roles: Leadership in the 21st century. Org. Dyn. 2000, 28, 18-34. [CrossRef]

26. Gwynne, P. Open innovation's promise and perils. Res. Technol. Manag. 2007, 50, 8-9. 
27. Dodgson, M.; Gann, D.; Salter, A. The role of technology in the shift towards open innovation: The case of Procter \& Gamble. R D Manag. 2006, 36, 333-346.

28. Huston, L.; Sakkab, N. Connect and develop. Harvard Bus. Rev. 2006, 84, 58-66.

29. Rao, B.; Jimenez, B. A comparative analysis of digital innovation ecosystems. In Proceedings of the Technology Management in the Energy Smart World (PICMET), Portland, OR, USA, 31 July-4 August 2011.

30. Frenkel, A.; Maital, S. Mapping National Innovation Ecosystems: Foundations for Policy Consensus; Edward Elgar: Cheltenham, UK, 2014.

31. Adner, R. Match your innovation strategy to your innovation ecosystem. Harvard Bus. Rev. 2006, 84, 98-107.

32. Adomavicius, G.; Bockstedt, J.C.; Gupta, A.; Kauffman, R.J. Technology roles and paths of influence in an ecosystem model of technology evolution. Inf. Technol. Manag. 2007, 8, 185-202. [CrossRef]

33. Gawer, A.; Henderson, R. Platform Owner entry and innovation in complementary markets: Evidence from Intel. J. Econ. Manag. Strateg. 2007, 16, 1-34. [CrossRef]

34. Lee, D.; Mendelson, H. Divide and conquer: Competing with free technology under network effects. Prod. Oper. Manag. 2008, 17, 12-28. [CrossRef]

35. Yan, M.R.; Chien, K.M.; Hong, L.Y.; Yang, T.N. Evaluating the collaborative ecosystem for the innovation-driven economy: A systems analysis and case study of science parks. Sustainability 2018, 10, 887. [CrossRef]

36. Vargo, S.L.; Wieland, H.; Akaka, M.A. Innovation through institutionalization: A service ecosystems perspective. Ind. Mark. Manag. 2015, 44,63-72. [CrossRef]

37. Paladino, A. Investigating the Drivers of innovation and new product success: A comparison of strategic orientations. J. Prod. Innov. Manag. 2007, 24, 534-553. [CrossRef]

38. Mu, J.; Thomas, E.; Peng, G.; Di Benedetto, A. Strategic orientation and new product development performance: The role of networking capability and networking ability. Ind. Mark. Manag. 2017, 64, 187-201. [CrossRef]

39. Park, J.H.; Lee, B.; Moon, Y.H.; Kim, G.; Kwon, L.N. Relation of R\&D expense to turnover and number of listed companies in all industrial fields. J. Open Innov. Technol. Mark. Compl. 2018, 4, 9.

40. Yan, M.R. Project-based competition and policy implications for sustainable developments in building and construction sectors. Sustainability 2015, 7, 15423-15448. [CrossRef]

41. Schiuma, G.; Carlucci, D.; Sole, F. Applying a systems thinking framework to assess knowledge assets dynamics for business performance improvement. Expert Syst. Appl. 2012, 39, 8044-8050. [CrossRef]

42. Yan, M.R. Strategic product innovations and dynamic pricing models in oligopolistic market. J. Sci. Ind. Res. 2017, 76, 284-288.

43. Schot, J.; Geels, F.W. Strategic niche management and sustainable innovation journeys: Theory, findings, research agenda, and policy. Technol. Analysis Strateg. Manage. 2008, 20, 537-554. [CrossRef]

44. Yun, J.J.; Won, D.; Park, K. Dynamics from open innovation to evolutionary change. J. Open Innov. Technol. Mark. Complex. 2016, 2, 7. [CrossRef]

45. Nambisan, S.; Baron, R.A. Entrepreneurship in innovation ecosystems: Entrepreneurs' self-regulatory processes and their implications for new venture success. Entrep. Theory Pract. 2013, 37, 1071-1097. [CrossRef]

46. Chesbrough, H.; Vanhaverbeke, W.; West, J. New frontiers in open innovation; Oxford University Press: Oxford, UK, 2014.

47. Thorlli, H.B. Networks: Between markets and hierarchies. Strateg. Manag. J. 1986, 7, 37-51. [CrossRef]

48. Goto, K. Social networks, informal trade credit and its effects on business growth: Evidence from the local garment trade in Vietnam. J. Asia Pac. Econ. 2013, 18, 382-395. [CrossRef]

49. Powell, W. Neither market nor hierarchy: Network forms of organization. Res. Org. Behavior 1990, 12, 295-336.

50. Autio, E.; Thomas, L. Innovation ecosystems: Implications for innovation management. In The Oxford Handbook of Innovation Management; Oxford University Press: Oxford, UK, 2013.

51. Tripsas, M. Unraveling the process of creative destruction: Complementary assets and incumbent survival in the typesetter industry. Strateg. Manag. J. 1997, 18, 119-142. [CrossRef]

52. Moore, J.F. The Death of Competition: Leadership and Strategy in the Age of Business Ecosystems; HarperCollins: New York, NY, USA, 1996. 
53. Yun, J.J.; Won, D.; Jeong, E.; Park, K.; Yang, J. and Park, J. The relationship between technology, business model, and market in autonomous car and intelligent robot industries. Technol. Forecast. Soc. Chang. 2016, 103, 142-155. [CrossRef]

54. Yun, J.J.; Won, D.; Park, K.; Yang, J.; Zhao, X. Growth of a platform business model as an entrepreneurial ecosystem and its effects on reginal development. Eur. Plann. Stud. 2017, 25, 805-826. [CrossRef]

55. Wernerfelt, B. A resource-based view of the firm. Strateg. Manag. J. 1984, 5, 171-180. [CrossRef]

56. Dyer, J.H.; Singh, H. The relational view: Cooperative strategy and sources of interorganizational competitive advantage. Acad. Manag. Rev. 1998, 23, 660-679. [CrossRef]

57. Kapoor, R.; Lee, J.M. Coordinating and competing in ecosystems: How organizational forms shape new technology investments. Strateg. Manag. J. 2013, 34, 274-296. [CrossRef]

58. Li, Y.; Liu, Y.; Zhao, Y. The role of market and entrepreneurship orientation and internal control in the new product development activities of Chinese firms. Ind. Mark. Manag. 2006, 35, 336-347. [CrossRef]

59. Baker, W.E.; Sinkula, J.M. The complementary effects of market orientation and entrepreneurial orientation on profitability in small businesses. J. Small Bus. Manag. 2009, 47, 443-464. [CrossRef]

60. Slater, S.F.; Narver, J.C. Market orientation and the learning organization. J. Mark. 1995, 59, 63-75. [CrossRef]

61. Atuahene-Gima, K.; and Ko, A. An empirical Investigation of The effect of market orientation and entrepreneurship orientation alignment on product innovation. Organ. Sci. 2001, 12, 54-74. [CrossRef]

62. Kohli, A.K.; Jaworski, B.J. Market orientation: The construct, research propositions, and managerial implications. J. Mark. 1990, 54, 1-18. [CrossRef]

63. Miller, D. The correlates of entrepreneurship in three types of firms. Manag. Sci. 1983, 29, 770-791. [CrossRef]

64. Sussan, F.; Kim, K.C.; Chinta, R.R.; Enriquez, J.L. Trade-off between creativity and productivity in technology-based SMEs performance: Policy implications in South Korea. J. Asia Pac. Econ. 2017, 22, 510-524. [CrossRef]

65. Lumpkin, G.; Dess, G. Enriching the entrepreneurial orientation construct-a reply to entrepreneurial orientation or pioneer advantage. Acad. Manag. Rev. 1996, 21, 605-607.

66. Foxall, G. Corporate innovation: Marketing and strategy; Croom Helm: Beckenham, UK, 1984.

67. Zampetakis, L.A.; Vekini, M.; Moustakis, V. Entrepreneurial orientation, access to financial resources, and product performance in the Greek commercial TV industry. Serv. Ind. J. 2011, 31, 897-910. [CrossRef]

68. Caruana, A.; Ewing, M.T.; Ramaseshan, B. Effects of some environmental challenges and centralization on the entrepreneurial orientation and performance of public sector entities. Serv. Ind. J. 2002, 22, 43-58. [CrossRef]

69. Van Riel, A.C.R.; Semeijn, J.; Hammedi, W.; Henseler, J. Technology-based service proposal screening and decision-making effectiveness. Manag. Decision. 2011, 49, 762-783. [CrossRef]

70. Kim, H.J.; McCahon, C.; Miller, J. Service orientation for contact employees in Korean casual-dining restaurants. Int. J. Hosp. Manag. 2003, 22, 67-83. [CrossRef]

71. Kumar, V.; Ramani, G. Interaction orientation: The new marketing competency. In Does Marketing Need Reform?: Fresh Perspectives on the Future; Routledge: Abingdon-on-Thames, UK, 2006.

72. Morris, M.H.; Coombes, S.; Schindehutte, M.; Allen, J. Antecedents \& outcomes of entrepreneurial \& market orientations in a non-profit context: Theoretical \& empirical insights. J. Leadership \& Org. Stud. 2007, 13, 12-39.

73. Wagener, S.; Gorgievski, M.; Rijsdijk, S. Businessman or host? Individual differences between entrepreneurs and small business owners in the hospitality industry. Serv. Ind. J. 2010, 30, 1514-1527. [CrossRef]

74. Hult, G.T.M.; Snow, C.C.; Kandemir, D. The role of entrepreneurship in building cultural competitiveness in different organizational types. J. Manag. 2003, 29, 401-426.

75. Sciascia, S.; Naldi, L.; Hunter, E. Market orientation as determinant of entrepreneurship: An empirical investigation on SMEs'. Int. Entrep. Manag. J. 2006, 2, 21-38. [CrossRef]

76. Barrett, H.; Weinstein, A. The effect of market orientation and organizational flexibility on corporate entrepreneurship. Entrep. Theory Pract. 1998, 23, 57-70. [CrossRef]

77. Morris, M.H.; Gordon, W.P. The relationship between entrepreneurship and marketing in established firms. J. Bus. Venturing. 1987, 2, 247-259. [CrossRef]

78. Eisenhardt, K.M. Building theories from case study research. Acad. Manag. Rev. 1989, 14, 532-550. [CrossRef]

79. Lee, T.L.; Mitchell, T.R.; Sablynski, C.J. Qualitative research in organizational and vocational psychology: 1979-1999. J. Vocat. Behav. 1999, 55, 161-187. [CrossRef]

80. Yin, R.K. Case Study Research Design and Methods; Blackwell Science Ltd.: London, UK, 2013. 
81. Charmaz, K. Constructing Grounded Theory: A Practical Guide through Qualitative Analysis; SAGE Publishing: Thousand Oaks, CA, USA, 2006.

82. Lincoln, Y.S.; Guba, E.G. Naturalistic inquiry; SAGE Publishing: Beverly Hills, CA, USA, 1985.

83. Bogdan, R.C.; Biklen, S.K. Qualitative Research for Education: An Introductory to Theory and Methods, 5th ed.; Allyn and Bacon: Boston, MA, USA, 2006.

84. Locke, K. Grounded Theory in Management Research; Sage: Thousand Oaks, CA, USA, 2003.

85. León, G. Gonzalo Leon, Analysis of University-driven Open Innovation Ecosystems: The UPM Case Study. R D Manag. 2013, 12, 321-336.

86. Fetters, M.L.; Greene, P.G.; Rice, M.P.; Butler, J.S. The Development of University-Based Entrepreneurship Ecosystems; Edward Elgar Publishing: Cheltenham, UK, 2010.

87. Oh, D.S.; Phillips, F.; Park, S.; Lee, E. Innovation ecosystems: A critical examination. Technovation 2016, 54, 1-6. [CrossRef]

88. Ireland, R.D.; Webb, J.W. Crossing the great divide of strategic entrepreneurship: Transitioning between exploration and exploitation. Bus. Horizons. 2009, 52, 469-479. [CrossRef]

89. Auh, S.; Menguc, B. Balancing exploration and exploitation: The moderating role of competitive intensity. J. Bus. Res. 2005, 58, 1652-1661. [CrossRef]

90. Mosey, S. Understanding new-to-market product development in SMEs. Int. J. Opera. Prod. Manag. 2005, 25, 114-130. [CrossRef]

91. Huang, H.; Chen, J.; Yu, F.; Zhu, Z. Establishing the enterprises' innovation ecosystem based on dynamics core competence- The case of China's high-speed railway. Emerg. Mark. Financ. Trad. 2019, 55, 843-862. [CrossRef]

92. Xu, Q.; Chen, J.; Xie, Z.; Liu, J.; Zheng, G.; Wang, Y. Total innovation management: A novel paradigm of innovation management in the 21st century. J. Technol. Trans. 2007, 32, 9-25. [CrossRef]

(C) 2019 by the authors. Licensee MDPI, Basel, Switzerland. This article is an open access article distributed under the terms and conditions of the Creative Commons Attribution (CC BY) license (http://creativecommons.org/licenses/by/4.0/). 